\title{
Mediating Effect of Preventive Measures on Food Safety Knowledge and Food Hygiene Practices
}

\author{
Saidatul Afzan Abdul Aziz ${ }^{1}$, Hayati Mohd Dahan² \\ ${ }^{1}$ Faculty of Hotel and Tourism Management, \\ Universiti Teknologi MARA, 42300 Bandar Puncak Alam, Selangor, Malaysia. \\ ${ }^{2}$ Faculty of Business Management, Universiti Teknologi MARA, 40450 Shah Alam, Selangor, Malaysia \\ saida509@salam.uitm.edu.my
}

\begin{abstract}
Food borne diseases represent a persistent public health problem in developed and developing countries. This study investigates if preventive measures mediate the relationship between food safety knowledge among food handlers and their food handling behaviours. Data is gathered from a sample of 300 food handlers attached to school canteens in four zones in Peninsular Malaysia. Using Amos 22.0, the finding indicates that there is partial mediation effect. As such, this research emphasizes the importance of preventive measure in food service operation which is critical to food hygiene training program as this may result in exhibited behavioural change in safe food handling.
\end{abstract}

Keywords: Food safety knowledge, Food handlers, Preventive measures, Food hygiene practices

eISSN 2398-4295 @ 2018. The Authors. Published for AMER ABRA cE-Bs by e-International Publishing House, Ltd., UK. This is an open-access article under the CC BY-NC-ND license (http://creativecommons.org/licenses/bync-nd/4.0/). Peer-review under responsibility of AMER (Association of Malaysian Environment-Behaviour Researchers), ABRA (Association of Behavioural Researchers on Asians) and cE-Bs (Centre for EnvironmentBehaviour Studies), Faculty of Architecture, Planning \& Surveying, Universiti Teknologi MARA, Malaysia. http://dx.doi.org/10.21834/ajbes.v3i11.108 


\subsection{Introduction}

Institutional foodservice, also known as non-commercial food service is defined as food service that functions without the objective of making profit (Payne, Palacio and Theis, 2001). Institutional food service are operations that serve people who are members of particular societal institution such as hospital, schools, nursing homes, military and manufacturing foodservice industry. Schools serving foods were initially introduced in early 1900 due to rising concern over children's health, especially those in poorer areas where the children were shorter and thinner (Yabanci and Sanlier, 2007). The food program is aimed to provide foods during the day for children who came from less fortunate background (Seaman and Eves, 2006). School meals during that period were also found to be the most important meal of the day since the children did not have proper meals before or after the school period. (Moy, Gan and Siti Zaleha, 2006). Today, with increase affluence due to greater economic development in countries across the globe where both parents working is a norm, the aim of school catering is to ensure children have proper and healthy meal (Moy et, al., 2006). In fulfilment of the need and demand for healthy eating habits, school canteen will have to be a reliable partner in achieving the objective of offering healthy foods at reasonable price (Sharif, and Al-Malki, 2010).

Public involvements are required to improve food safety as part of the process of economic development and to help to understand the food safety system. Despite progress in modern technology, food contamination remains one of the most critical problem worldwide. On one hand, food provides nutrients required for a well and balanced diet to the human body, on the other, food can be a hazardous vehicle for transmission of risk factors causing food-borne diseases (Yabanci and Sanlier, 2007). This includes cholera, typhoid fever, hepatitis A, dysentery and food poisoning. Food-borne diseases are widespread, both in developed and more so in developing countries. It is of great concern as World Health Organization (WHO, 2007) reported that in the year 2005, 1.8 million people died from diarrhoea, one of the many food-borne diseases. For this reason, in recent years, food-borne diseases have captured increased public attention worldwide. Five risk factors had been identified by the Centre Disease Control and Prevention (CDC, 2000) on food handling that added on to food-borne illnesses, this include improper cooking procedure; temperature abuse during storage; lack of hygiene and sanitation by food handlers; cross contamination between raw and fresh ready to-eat foods; and, acquiring food from unsafe sources. From these five factors, four are directly related to food handlers (WHO, 2007). As a result, it is the utmost responsibility of the society; especially the school authorities and parents' association to address these issues in support of a safe environment to ensure safer food and healthy eating patterns. In this context, it is essential to examine the mediating effect of prevention measures on food safety knowledge and food hygiene practices.

\subsection{Literature Review}

Food and Agriculture Organization (FAO)/World Health Organization (WHO) (2004) estimated approximately 2 million children in developing countries die each year from 
diarrhoea caused from food-borne diseases. Besides, an increased in number of occurrences by various causes, the majority of outbreaks occurred in schools (WHO, 2008). Students are captive customers, who are usually incapable to purchase food from external sources during the six hours they are at school. It is important for schools to manage their shared responsibility to provide nutritious and safe food to their students. School meals are significant because they are one of the most apparent instruments for policy intervention in children's diet to uphold the development of healthy eating patterns (Moy, Gan and Siti Zaleha, 2006; Yabanci and Sanlier, 2007). Moreover, school meals are now more imperative than in the past, since children rely on the canteen to offer their entire meal from breakfast to lunch. As such, the school should ensure secure and healthy food for the students which will influence their health and academic performance (Moy et al , 2006; Veiros, et. al., 2009). The Ministry of Health, Malaysia $(\mathrm{MOH}, 2007)$ reported in 2006 that the incident rate for food poisoning was 26.04 per 100,000 people. However, WHO (2008) reported a rise in incidence rates for food poisoning to 52.6 per 100,000 in the year 2007, this being one of the top five noticeable diseases in Malaysia. In line with such report, there was in fact an increase in the number of episodes of food-borne outbreak reported by various states in Malaysia. This include outbreaks occurring in schools (Zain and Naing, 2002; WHO, 2008;Sharif and AlMalki, 2010). Moreover, an epidemiology study found that since the year 1997, food-borne outbreaks increased 66.5\% among the schooling age group in Malaysia (Meftahuddin, 2002; Naing, Zain, Hamzah, Mat, Abdullah and Bakar, 2007). In Malaysia, food poisoning recorded the highest incidence rate of communicable disease in the food and water borne disease category (44.18 per 100,000 populations) as presented in Table 1 (MOH, 2011).

Table 1: Incidence rate and mortality rate of communicable disease per 100,000 populations in Malaysia

\begin{tabular}{|l|l|l|}
\hline \multicolumn{4}{|l|}{ Food and Water Borne Diseases } \\
\hline Communicable Diseases & Incidence Rate & Mortality Rate \\
\hline Cholera & 1.56 & 0.02 \\
\hline Dysentery & 0.37 & 0 \\
\hline Food Poisoning & 44.18 & 0 \\
\hline Typhoid & 0.74 & 0 \\
\hline Hepatitis A & 0.14 & 0 \\
\hline
\end{tabular}

(Source: Ministry of Health Malaysia: 2011)

Previous record showed that $48 \%$ of the total food poisoning cases in year 2007 actually took place in schools within Selangor, Perlis, Kedah, Perak, Sabah and Kelantan. Schools located in these six states have the most reported cases (Utusan, 2008). On a smaller scale in 2008 , Pahang traced more than $71 \%$ of their overall food poisoning cases in school canteen (Utusan, 2008). A further report revealed more than $88 \%$ of food poisoning cases in Johor apparently involved students (Utusan, 2009). The Health Minister, Datuk Seri Liow made known in his speech that $50 \%$ of the total food poisoning outbreaks in 2010 took place 
in schools (Utusan, 2011). Furthermore, he listed contamination during food preparation, storing, delivery and serving as the core causes of food poisoning.

These incidences established that schoolchildren are the vulnerable group to become victim of food poisoning, particularly Malaysia. Children with existing health situation or weakened immune systems are more at risk of getting ill from food poisoning than those who are in good health. As one of the many types of foodservice operations, school canteens are most frequently cited as locations for outbreaks of food borne disease (Seaman, 2010; Sanlier and Konaklioglu, 2012). Despite an increase in the number of food handlers attending food hygiene course, a high proportion of food poisoning outbreaks still occur because of poor food handling practices (Liow, 2011). Children are most vulnerable to food-borne diseases because their immune systems are not fully developed (McSwane, Rue and Linton, 2003). Therefore, prevention of food-borne diseases in children requires a multidisciplinary approach, including safe preparation and handling of food; concurrently education for parents and food handlers. As a result, it is the ultimate responsibility of the society especially the school authorities and parents' association to address these issues and ensure safe environment, which maintain safer food and healthy eating patterns.

According to Namkung and Jang (2007) and Nieto-Montenegro, Brown and Labarde (2008), besides serving contaminated raw food, food handling mistakes generally include inadequate cooking, heating, or re-heating of food consumption of food from unsafe sources, cooling food inappropriately and allowing too much of time lapse. These errors can lead to food poisoning. Many studies identify the need for training and education of food handlers in public hygiene measures due to the need of knowledge on microbiological food hazards, temperature ranges of refrigerators, cross contamination and personal hygiene (Ogden, 2003; Bas et. al., 2004; Worsfold and Griffith, 2010). Food safety knowledge among food handlers is vital in all food service establishments, no matter what circumstances take place. The seriousness of poor food safety in any food industry should be a major concern to prevent food contaminations which will result to foodborne illness (Campos, Cardonha, Pinheiro, Ferreira, Azevedo and Stamford, 2009). It is important to expose all food handlers to relevant knowledge and education through training as these may increase food handlers' knowledge, attitudes, and practices when handling or when in contact with food (CDC, 2011, 2009). There is general agreement that good overall levels of knowledge of food safety among food handlers and the effective application of such knowledge in food handling practices are essential in ensuring the consistent production of safe food in restaurant operations (Mortlock, Peters, \& Griffith, 1999).Education of food industry personnel in hygiene matters has been recommended by means of improving food handling practices and thus the safety of food (Clayton\& Griffith, 2004). There is, however, a lack of documentary evidence of improvements in food hygiene standards which can be directly related to education or training (Rennie, 1995). It is significant that food service establishments recognize the importance of food safety and voluntarily introduce measures to prevent foodborne illnesses (Motarjemi \& Kaferstein, 1999). Preventive measures are aimed at creating circumstances to prevent entry and or growth of pathogens in food production systems (Baert et al., 2005, Escriche et al., 2006 \& Luning et al., 2006). Therefore, preventive measures influence food safety by 
reducing the chance on (cross) contamination or growth, and it may improve efficiency and effectiveness of food safety by decreasing the number of critical control points (Vladimirov, 2011).

\subsection{Methodology}

Three hundred and sixty four respondents were proportionately selected randomly from four urban areas representing four zones in Peninsular Malaysia namely Alor Setar (Kedah), Kuantan (Pahang), Shah Alam (Selangor) and Melaka by using cluster sampling resulting in a response rate of $72.6 \%$. The respondents were among food handlers in primary school canteens. This study employed self-administered questionnaire for data collection. Respondents responded at their convenient time, without the pressure of hurrying (Sekaran, 2010). The structured questionnaire is intended to measure all constructs. The development of the questionnaire revolves around food hazards, food temperature and food contamination, monitoring and food hygiene practices. The respondents were asked to rate on a seven-point Likert scale, ranging from 1 (strongly disagree) to 7 (strongly agree). The data collection period took approximately three months to complete. Data gathered were analysed by using AMOS Structural Equation Modeling (SEM) to test the mediating effect of preventive measures on both the predictor and outcome variables. The researcher in particular is interested to investigate the mediating effect of preventive measure to food safety knowledge and food hygiene practices.

\subsection{Results and Discussions}

The data analyses were conducted by AMOS 22.0 software. First, analysis of covariance structure was used to examine the mediation model and investigate the causal relations between the main variables. Second, bootstrapping procedures were implemented to obtain estimates of the indirect effects and to test their significance by using confidence intervals. If a zero is not included in the $95 \%$ confidence interval of the estimate, it means that the indirect effect is statistically significant. The bootstrapping method is recommended to overcome potential problems caused by unmet assumptions.

\section{Analysis of Research Model}

Before analyzing the structural model, the goodness of measurement model fit was tested to examine how well the model fits the data. Fit indices such as GFI, CFI and RMSEA were used to examine the goodness of model fit. According to cutoff criteria for fit indices (Zainuddin, 2012), goodness of model fit was acceptable. Table 2 summarizes the result of goodness of fit for measurement and structural model.

Figure 1 shows the significant paths with standardized regression coefficients of mediation model. First, the path between food safety knowledge and food hygiene practices is significant $\left.{ }_{\beta}=0.30, p<.001\right)$, indicating that food handlers who had knowledge on food safety are aware of preventive measure conducted by school administrator. Second, there is 
a significant effect of preventive measure on food hygiene practices $(\beta=0.45, p<.001)$ which suggested that the food handlers are also aware of preventive measure that will likely lead to the practice of safe food handling. Third, there is a significant effect of food safety knowledge on food hygiene practice. This result show that the mediation is partial since the direct effect is still significant after introducing the mediator variable into the models.

Table 2: Goodness of Model Fit

\begin{tabular}{|c|c|c|c|}
\hline Name of category & Name of Index & Index value & Comments \\
\hline 1. Absolute fit & RMSEA & 0.088 & The required level is achieved \\
\hline Absolute fit & GFI & 0.715 & The required level is moderately achieved \\
\hline 2. Incremental fit & CFI & 0.774 & The required level is moderately achieved \\
\hline 3. Parsimonious fit & Chisq/df & 3.321 & The required level is achieved \\
\hline
\end{tabular}

Note: $\mathrm{GFI}=$ goodness of fit index, $\mathrm{CFI}=$ comparative fit index, RMSEA=root mean square error of approximation

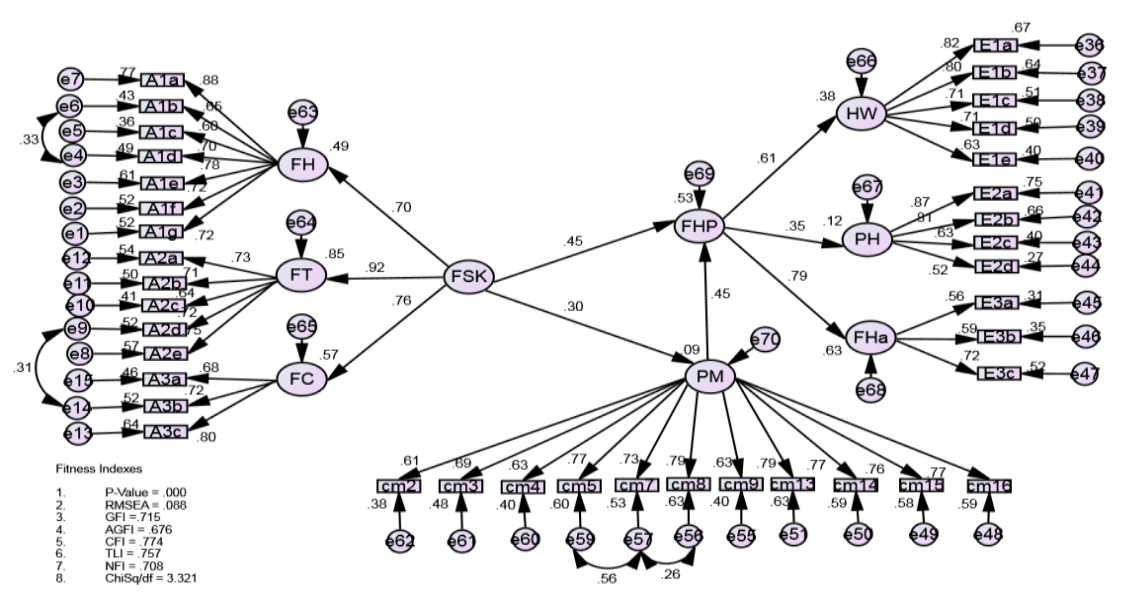

Figure 1: Mediation Model with Standardized Regression Coefficient.

To examine the total indirect effect of food safety knowledge on food hygiene practices through preventive measure, the bootstrapped estimate was implemented from the main analysis. As a result, the total indirect effect was statistically significant, as the confidence intervals didn't contain a zero (see Table 3). This indicates that greater food safety knowledge among food handler is positively related to preventive measure and it is also related to a safe food handling behavior. 
Table 3: Path Coefficients of Mediation Model

\begin{tabular}{|c|c|c|c|c|c|c|c|c|}
\hline $\begin{array}{c}\text { Construc } \\
t\end{array}$ & & & $\begin{array}{c}\text { Coefficien } \\
t\end{array}$ & S.E. & C.R. & $\begin{array}{c}\text { P- } \\
\text { Valu } \\
\text { e }\end{array}$ & $\begin{array}{l}\text { Bootstrappin } \\
\mathrm{g} \\
\text { BC 95\% Cl } \\
\text { Lower }\end{array}$ & $\begin{array}{c}\text { Bootstrappin } \\
\mathrm{g} \\
\mathrm{BC} 95 \% \mathrm{Cl} \\
\text { upper }\end{array}$ \\
\hline $\begin{array}{l}\text { Preventive } \\
\text { Measure }\end{array}$ & $<-$ & $\begin{array}{c}\text { Food } \\
\text { Safety } \\
\text { Knowledg } \\
\text { e }\end{array}$ & $.339^{\star \star *}$ & $\begin{array}{c}.08 \\
0\end{array}$ & $\begin{array}{c}4.22 \\
2\end{array}$ & $\begin{array}{c}0.00 \\
1\end{array}$ & 0.163 & 0.443 \\
\hline $\begin{array}{l}\text { Food } \\
\text { Hygiene } \\
\text { Practice }\end{array}$ & $\begin{array}{l}<- \\
-\end{array}$ & $\begin{array}{c}\text { Food } \\
\text { Safety } \\
\text { Knowledg } \\
\text { e }\end{array}$ & $.133^{\star \star \star}$ & $\begin{array}{l}.03 \\
7\end{array}$ & $\begin{array}{c}3.55 \\
5\end{array}$ & $\begin{array}{c}0.00 \\
1\end{array}$ & 0.382 & 0.754 \\
\hline $\begin{array}{l}\text { Food } \\
\text { Hygiene } \\
\text { Practice }\end{array}$ & $<-$ & $\begin{array}{c}\text { Preventive } \\
\text { Measure }\end{array}$ & $.119^{\star \star \star}$ & $\begin{array}{c}.03 \\
2\end{array}$ & $\begin{array}{c}3.76 \\
7\end{array}$ & $\begin{array}{c}0.00 \\
1\end{array}$ & 0.213 & 0.656 \\
\hline
\end{tabular}

\subsection{Conclusion}

The present study tested a mediation model in which preventive measure served as mediating variables in the relationship between food safety knowledge and food hygiene practices. The findings demonstrated that all the paths of the mediation model were significant. These results were consistent with the previous studies that stated the importance of preventive measure in food service establishment. That is, food handlers who have food safety knowledge were likely aware the importance of preventive measure and it may lead to safe food handling in the food service operation. These results imply that there are multiple factors that influence increasing knowledge among food handler, and that omitting other important factors can produce an error when analyses are limited to examining just one factor. Therefore, broadening the previous studies and examining food handlers' food safety knowledge simultaneously can contribute to the areas of food hygiene practice and public health education settings.

\section{References}

Bas, M., Ersun, A. S., \& Kivanc, G. (2006). The Evaluation of Food Hygiene Knowledge, Attitudes, and Practices of Food Handlers' in Food Businesses in Turkey. Food Control, 17, 317-322

Clayton, D. A., \& Griffith, C. J. (2004). Observation of Food Safety Practices in Catering using Notational Analysis. British Food Journal, 106 (3), 211-227.

Codex Alimentarius Commission, Joint FAO/WHO Standards Programme. (2003). Food hygiene: Basic texts. $2^{\text {nd }}$ Edition. 
Compos, A. K. C., Cardonha, A. M. S., Pinheiro, L. B. G., Ferreira, N. R., Azevedo, P. R. M., \& Stamford, T. L. M. (2009). Assessment of personal hygiene and practices of food handlers in municipal public schools of Natal, Brazil. Food Control, 20,807-810.

Food and Agriculture Organization/World Health Organization. (2004). Regional conference on Food Safety for the Asia and the Pacific, Seremban. Retrieved from www.fao.org/DOCREP/MEETING/006/AD698E.HTM.

Food Quality Control Division by Ministry of Health Malaysia. (2009) Food Act 1983 (Food Hygiene Regulations, 2009). Retrieved from http://fsq.moh.gov.my/modules.

I. Escriche, E. Doménech, K. Baert (2006). Design and Implementation of an HACCP system, Safety in agri-food chains, Wageningen Academic Publishers, Wageningen, pp. 303-354

K. Baert, F. Devlieghere, L. Jacxsens, J. Debevere (2005). Quality management systems in the food industry

McSwane, D., Rue, N., \& Linton, R. (2003). Essentials of Food Safety and Sanitation. Third Edition. Pearson Education. New Jersey.

Meftahuddin, T. (2002). Review of the trends and causes of food borne outbreaks in Malaysia from 1988 to 1997. Medical Journal Malaysia,57(1),70-9.

Ministry of Education, Malaysia. (2008). Number of Government Assisted School 2003-2007. Retrieved from: http://www.moe.gov.

Ministry of Health (2011). Health facts 2010. Retrieved June 21, 2013 from www.moh.com.my.

Ministry of Health, Malaysia. (2007). Incidence rate and mortality rate of communicable disease per 100,000 population in 2006. Retrieved from http://www.moh.gov.

Moy, F.M., Gan, C. Y. \& Siti Zaleha M. K. (2006). Eating patterns of school children and Adolescents in Kuala Lumpur. Malaysia Journal Nutrition, 12 (1),1-10.

Naing, N. N., Zain, M. M., Hamzah, W. M., Mat, H.A., Abdullah, N., \& Bakar, A. M. H. (2007). A study on effective of health educatin program on knowledge, attitude and practice (KAP) of food handlers towards food-borne disease and food safety. International medical journal Tokyo, 14(4), 253-260.

Namkung, Y., \& Jang, S., (2007). Does Food Quality Really Matter in Restaurants? Its Impact on Customer Satisfaction and Behavioral Intentions. Journal of Hospitality Management. 27(1), $23-29$.

Nieto-Montenegro, S., Brown, J. L., \& Laborde, L. F. (2008). Development And Assessment Of Pilot Food Safety Educational Materials And Training Strategies For Hispanic Workers In The Mushroom Industry Using The Health Action Model. Food Control, 19(6), 616-633. Doi:10.1016/J.Foodcont.2007.07.005

Ogden, J. (2003). Some Problems With Social Cognition Models: A Pragmatic And Conceptual Analysis. Health Psychology, 22(4), 424-428. Doi:10.1037/0278-6133.22.4.424

Olsen, S. J., MacKinon, L. C., Goulding, J. S., Bean, N. H., \& Slutsker, L. (2000). Surveillance for food-borne disease outbreak in United States, 1993-1997. Retrieved from: http//www. Cdc.gov/epc/mmwr/preview/mmwrhtml/ss4901a1.htm.

P.A. Luning, M. Van der Spiegel, W.J. Marcelis (2006). Quality assurance systems and food safety: Safety in agrifood chains, Wageningen Academic Publishers, Wageningen (2006), pp. 249-302 
Abdul Aziz, S.A., \& Mohd Dahan, H. / Asian Journal of Behavioural Studies (AjBeS), 3(11) May / Jun 2018 (p.127-136)

Payne-Palacio, J., \& Theis, M. (2001). Introduction to foodservice. $9^{\text {th }}$ edition. Prentice Hall Inc.

Rennie, D. M. (1995). Health Education Models And Food Hygiene Education. The Journal Of The Royal Society For The Promotion Of Health, 115(2), 75-79. Doi:10.1177/146642409511500203

Sanlier, N., \& Konaklioglu, E. (2012). Food Safety Knowledge, Attitude And Food Handling Practices Of Students. British Food Journal, 114(4), 469-480. Doi:10.1108/00070701211219504

Seaman, P. (2010). Food Hygiene Training: Introducing The Food Hygiene Training Model. Food Control, 21(4), 381-387. Doi:10.1016/J.Foodcont.2009.08.005

Seaman, P., \& Eves, A. (2006). The management of food safety- the role of food hygiene training in the UK service sector. Hospitality Management, 25,278-296.

Selamat, J., Shamsudin, M. N., \& Dullati, M. S. (2002). Food Outlook: Malaysia. Pacific Food System Outlook 20022003, Pacific Economic Cooperation Councils. http://www.pecc.org/food

Sharif, L., \& Al-Malki, T. (2010). Knowledge, Attitude and Practice of Taif University Students on Food Poisoning. Food Control, 21, 55-60.

Singh, P., Fook, C.Y., \& Sidhu, G. K., (2008). A Comprehensive Guide to Writing A Research Proposal. Venton Publishing.

Spears, M.C. (2000) Foodservice Organizations: A managerial and systems approach. Fourth Edition. Prentice Hall. New Jersey.

St Kliment Ohridski University Press, Sofia

Utusan Online, (2009), Nov 16). Majoriti kes keracunan babitkan pelajar. Retrieved May 10, 2013, from www.utusan.com.my.

Utusan Online, (2011, March 30). 50\% kes keracunan makanan berlaku di kantin sekolah. Retrieved April 8, 2013, from www.utusan.com.my

Veiros, M. B., Proenca, R. P. C., Santos, M. C. T., Smith, L. K., \& Rocha, A. (2009). Food Safety Practices in a Portuguese Canteen. Food Control, 20,936-941.

Vemula, S. R., Kumar, R. N., \& Polasa, K. (2012). Foodborne Diseases In India - A Review. British Food Journal, 114(5), 661-680. Doi:10.1108/00070701211229954

Vladimirov, Z. (2011). Implementation Of Food Safety Management System In Bulgaria. British Food Journal, 113(1), 50-65. Doi:10.1108/00070701111097330

World Health Organization, (2008). Malaysia health situation and trend. Retrieved from www.wpro.who.int/countries/2008/maa/health_situation.htm.

World Health Organization. (2007). Food Safety and Foodborne Illness. Retrieved from: http://www.who.int/mediacentre/factsheets/fs237/en/print.html

Worsfold, D., \& Griffith, C. (2010). Experiences And Perceptions Of Secondary Food Hygiene Training: A Preliminary Study Of Five Larger Catering Companies In South East Wales. Perspectives In Public Health, 130(4), 173-179. Doi:10.1177/1757913908101798 
Abdul Aziz, S.A., \& Mohd Dahan, H. / Asian Journal of Behavioural Studies (AjBeS), 3(11) May / Jun 2018 (p.127-136)

Y. Motarjemi, F. Käferstein (1999). Food safety, Hazard Analysis and Critical Control Points and the increase in foodborne disease: a Paradox? Food Control, 10 (4-5), pp. 325-333

Yabanci, N., \& Sanlier, N. (2007). An assessment of hygienic conditions in nursery schools' kitchens. Nutrition \& Food Science, 37,(6),419-426.

York, V. K., Brannon, L. A, Shanklin, C. W., Roberts, K. R., Howells, A. D., \& Barrett, E. B. (2009). Foodservice Employees Benefit From Interventions Targeting Barriers To Food Safety. Journal Of The American Dietetic Association, 109(9), 1576-81. Doi:10.1016/J.Jada.2009.06.370

Zain, M. M., \& Naing, N. N., (2002). Southeast Asian Med Public Health Socio-demographic Characteristics Of Food Handlers And Their Knowledge , Attitude And Practice Towards Food Sanitation :, 33(2). 